\title{
High-resolution stratigraphy of the Changhsingian (Late Permian) successions of NW Iran and the Transcaucasus based on lithological features, conodonts and ammonoids
}

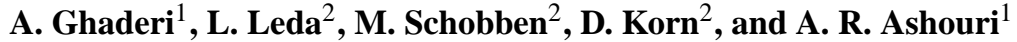 \\ ${ }^{1}$ Department of Geology, Faculty of Sciences, Ferdowsi University, Mashhad, Iran \\ ${ }^{2}$ Museum für Naturkunde, Leibniz-Institut für Evolutions- und Biodiversitätsforschung, \\ Invalidenstraße 43, 10115 Berlin, Germany
}

Correspondence to: A. Ghaderi (abbas.ghaderi@gmail.com)

Received: 31 December 2013 - Revised: 8 February 2014 - Accepted: 10 February 2014 - Published: 7 March 2014

\begin{abstract}
The Permian-Triassic boundary sections in northwestern Iran belong to the most complete successions, in which the largest mass extinction event in the history of the Earth can be studied. We investigated the Changhsingian stage in six sections in the area of Julfa (Aras Valley) for their lithology, conodonts and ammonoids. Revision of the biostratigraphy led to the separation of 10 conodont zones (from bottom to top Clarkina orientalis-C. subcarinata interval zone, C. subcarinata, C. changxingensis, C. bachmanni, C. nodosa, C. yini, C. abadehensis, C. hauschkei, Hindeodus praeparvus $-H$. changxingensis and Merrilina ultimaStepanovites ?mostleri zones) and 8 ammonoid zones (from bottom to top Iranites transcaucasius-Phisonites triangulus, Dzhulfites nodosus, Shevyrevites shevyrevi, Paratirolites trapezoidalis, P. waageni, Stoyanowites dieneri, Abichites stoyanowi and Arasella minuta zones). The new ammonoid genera Stoyanowites and Arasella are described.
\end{abstract}

\section{Introduction}

Permian-Triassic boundary sections in the vicinity of Julfa (East Azerbaijan Province, NW Iran) play a key role in the subdivision of the Late Permian sedimentary successions of the Palaeotethyan realm (Figs. 1, 2). The Changhsingian (latest Permian) deposits were accumulated on an outer shelf (Leda et al., 2014); they display a continuous succession and contain a considerably rich pelagic fauna consisting of conodonts and cephalopods, allowing for the separation of a number of biozones within this time unit.
While time-equivalent sedimentary successions in other regions such as South China have been studied in great detail (e.g. Sun et al., 2012; Romano et al., 2013, for more literature), the Transcaucasian and NW Iranian sections are known from fewer studies. Although sections in this region have attracted scientists for a long time (Abich, 1878; Frech and Arthaber, 1900; Bonnet and Bonnet, 1947), detailed lithostratigraphical and biostratigraphical studies of the Changhsingian sections in the Transcaucasus and NW Iran have only rarely been carried out. An exception is the conodont succession in these outcrops, which has been studied in greater detail by Kozur et al. (1980), Sweet and Mei (1999a, b), Partoazar (2002), Kozur (2004, 2005, 2007), Henderson et al. (2008) and Shen and Mei (2010). In addition, several investigations focused on the stable isotopes of the NW Iranian sections, such as $\delta^{13} \mathrm{C}$ (Baud et al., 1989; Korte et al., 2004; Richoz, 2006; Korte and Kozur, 2010; Richoz et al., 2010), $\delta^{18} \mathrm{O}$ (Schobben et al., 2013) and a Ce anomaly (Kakuwa and Matsumoto, 2006). These studies demonstrate the high potential for a subdivision of the Changhsingian stage of sections in the Palaeotethys, comparable or even finer than in the more intensely studied sections in South China.

In the following we present a correlation of lithostratigraphical data and the distribution of conodonts and ammonoids. It will be shown that the Changhsingian stage cannot only be subdivided into a number of zones by means of conodonts, but also of ammonoids. These two biostratigraphical subdivisions are supported by lithological characteristics. 

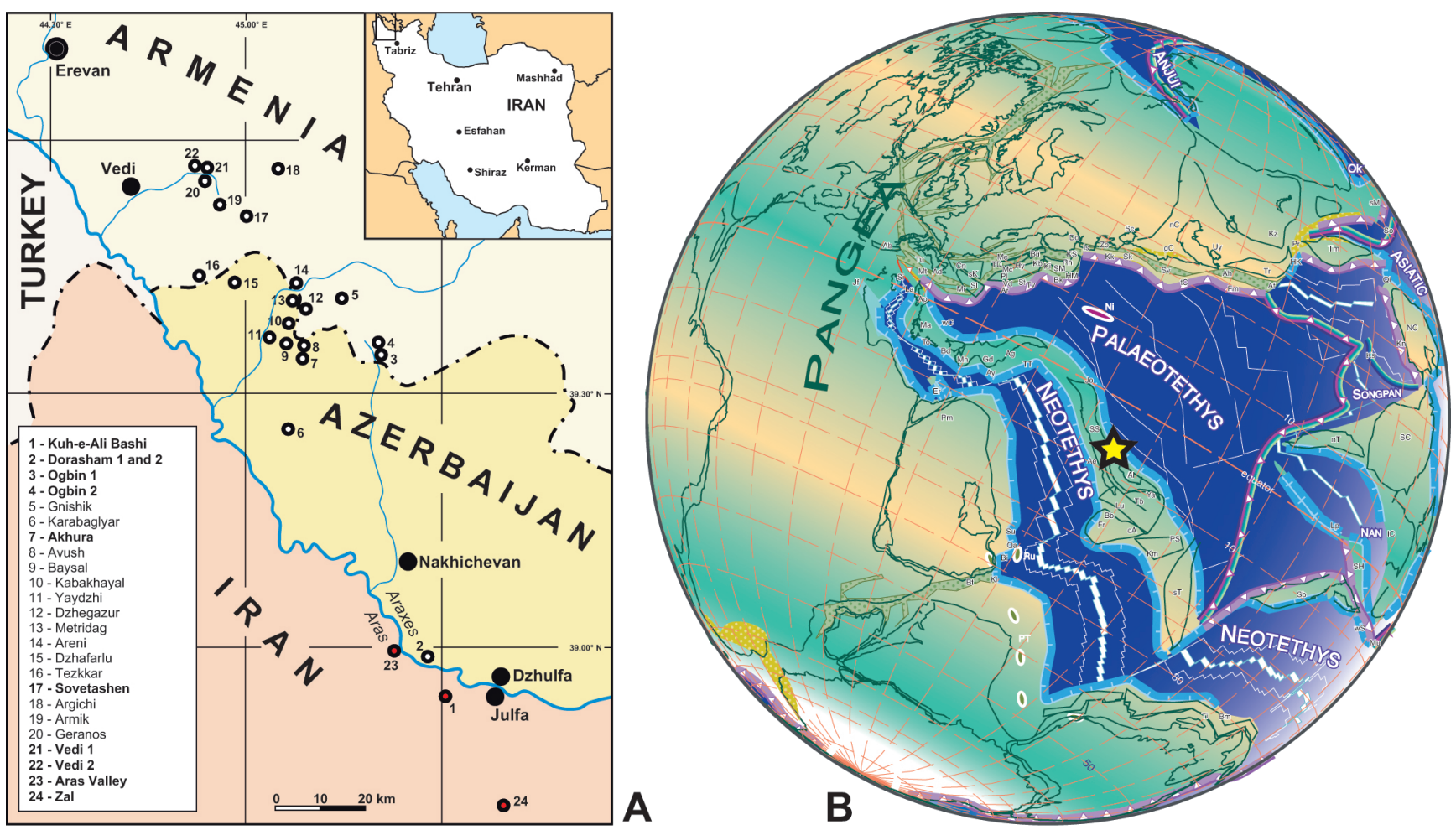

Figure 1. (A) Geographical position of Permian-Triassic boundary sections in the Transcaucasus and in NW Iran (after Arakelyan et al., 1965); sections investigated in this study are highlighted. (B) Palaeogeographic position of the Julfa area (after Stampfli and Borel, 2002).

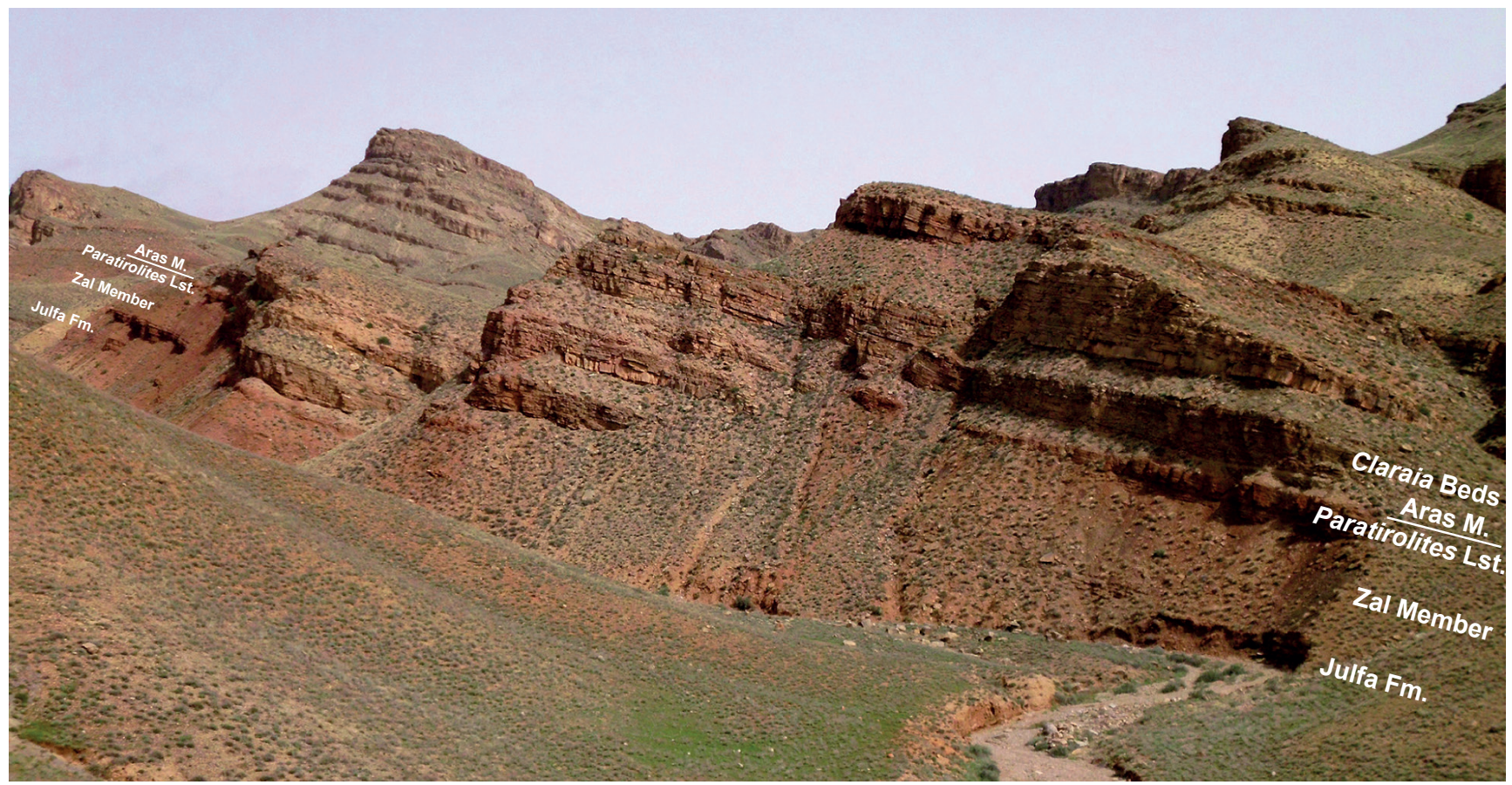

Figure 2. The Permian-Triassic boundary sections in the Ali Bashi Mountains, NW Iran. 


\section{Localities}

Sedimentary rocks representing the transition from the Palaeozoic into the Mesozoic in uninterrupted succession are very well exposed in the regions of Transcaucasia in Armenia, Azerbaijan and NW Iran (Fig. 1). The outcrops of Late Permian to Early Triassic successions studied by the authors are located south of the Aras (Araxes) River, which coincides with the political boundary between Iran and the province of Nakhichevan (Azerbaijan). The exposures are located west or south of the two neighbouring towns Dzhulfa (or Culfa, Nakhichevan province; Azerbaijan) and Julfa (or Jolfa, East Azerbaijan Province, Iran). We investigated and measured six fossil-rich pelagic Permian-Triassic $(\mathrm{P}-\mathrm{Tr})$ boundary sections in greater detail and recorded their petrography and carbonate microfacies as well as their conodont and ammonoid content:

(1) Aras Valley $\left(39.0154^{\circ} \mathrm{N}, 45.4345^{\circ} \mathrm{E}\right)$ : this section was described for the first time by Leda et al. (2014); it is situated about $19 \mathrm{~km} \mathrm{WNW}$ of the towns of Dzhulfa and Julfa in a dry small side valley west of the Aras (Araxes) River. The new section has a position approximately $2 \mathrm{~km}$ northwest of the Dorasham I section of Ruzhencev et al. (1965). A nearly complete Wuchiapingian and Changhsingian succession is exposed at this locality with a considerably good outcrop of the lower, shale-dominated part of the Changhsingian, a perfect outcrop of the Paratirolites Limestone over an extension of $200 \mathrm{~m}$ and a rather good exposure of the "boundary clay" (renamed Aras Member here).

(2) P-Tr boundary beds crop out in several parallel sections over a range of about $1.5 \mathrm{~km}$ in the Ali Bashi Mountains (i.e. Kuh-e-Ali Bashi) $9 \mathrm{~km}$ west of Julfa (Fig. 1). The sedimentary and faunal succession and the thickness of the various rock units principally parallel the section in the Aras Valley. Four of the numerous sections were measured and sampled by us:

(a) Ali Bashi 1 section $\left(38.9397^{\circ} \mathrm{N}, 45.5197^{\circ} \mathrm{E}\right)=$ Locality 1 of Teichert et al. (1973): it is the section described in detail by Teichert et al. (1973, p. 377). The section begins with red nodular marls and limestone beds of the upper part of the Wuchiapingian Julfa Formation (Vedioceras beds) and continues into the Early Triassic Elikah Formation. The entire Changhsingian succession is exposed in this section and allows for a detailed study.

(b) Ali Bashi 4 section $\left(38.9416^{\circ} \mathrm{N}, 45.5158^{\circ} \mathrm{E}\right)=$ Locality 4 of Teichert et al. (1973): it is the section described in detail by Stepanov et al. (1969) and Ghaderi et al. (2013); Teichert et al. (1973, p. 380) gave a brief description of the lower part of the section (for a discussion of the correlation of the Ali Bashi 1 and Ali Bashi 4 sections, see Leda et al., 2014, and particularly Ghaderi et al., 2013). It is the most complete of all the sections in the Ali Bashi Mountains (Fig. 3), beginning with the early Wuchiapingian Codonofusiella beds and ranging into the Elikah Formation. Unfortunately, the lower shaly part of the Ali Bashi Formation is largely covered by scree and hence accessible only by trenching.

(c) Ali Bashi $\mathrm{N}$ section $\left(38.9456^{\circ} \mathrm{N}, 45.5137^{\circ} \mathrm{E}\right)$ : the newly discovered section begins with poor outcrops in the lower part of the Ali Bashi Formation and ends in the Elikah Formation. The Paratirolites Limestone is well-exposed over a distance of $200 \mathrm{~m}$.

(d) Ali Bashi M section $\left(38.9354^{\circ} \mathrm{N}, 45.5238^{\circ} \mathrm{E}\right)=$ Locality 1 with the sections I-IV of Kozur (2005): the outcrop in the main valley of the Ali Bashi Mountains shows rather poor outcrop conditions, but the complete Changhsingian interval can be measured.

(3) Zal: this section is situated $22 \mathrm{~km} \mathrm{SSW}$ of Julfa and $2.2 \mathrm{~km} \mathrm{NNW}$ of the village of Zal $\left(38.7327^{\circ} \mathrm{N}\right.$, $\left.45.5795^{\circ} \mathrm{E}\right)$. Columnar sections have been published by Korte et al. (2004), Kozur $(2005,2007)$ and Shen and Mei (2010). Lasemi et al. (2007) investigated the sedimentology of the Wuchiapingian succession. It is one of the best outcrops of the Permian-Triassic transitional beds in NW Iran and exposes the entire Late Permian and a large part of the Early Triassic succession.

\section{Lithostratigraphy (Ghaderi, Leda, Schobben, Korn)}

Three lithological units represent the Changhsingian stage in the Transcaucasus and NW Iran: from bottom to top, a so far unnamed shaly member (described as Zal Member here), the Paratirolites Limestone (both together composing the Ali Bashi Formation), and the "boundary clay" (described here as the Aras Member and is the base of the mainly Triassic Elikah Formation). This lithological succession has already been outlined by a number of previous studies; Arakelyan et al. (1965) as well as Rostovtsev and Azaryan (1973) described the sections in Armenia and the Nakhichevan province of Azerbaijan (including the Dorasham sections), and Stepanov et al. (1969) as well as Teichert et al. (1973) described the Ali Bashi section.

In the following, we discuss the three rock units in terms of their lithological features in ascending order (Fig. 3).

1. Ali Bashi Formation - two members compose this formation: a lower shale-dominated and a so far unnamed member described here as the Zal Member, and an upper carbonatedominated member, for which the name Paratirolites Limestone has been coined.

(a) Zal Member (with the type locality in the Zal section $2.2 \mathrm{~km} \mathrm{NNW}$ of the village of Zal) - the member has a thickness of 12.5 to $20 \mathrm{~m}$ in the vicinity of Julfa, i.e. $20 \mathrm{~m}$ in the Dorasham section according to Arakelyan et al. (1965), $13.5 \mathrm{~m}$ in the Aras Valley section, $18 \mathrm{~m}$ in the Ali Bashi 4 section according to Stepanov et al. (1969), $12.5 \mathrm{~m}$ in the Ali Bashi 1 section according Teichert et al. (1973) as well as 


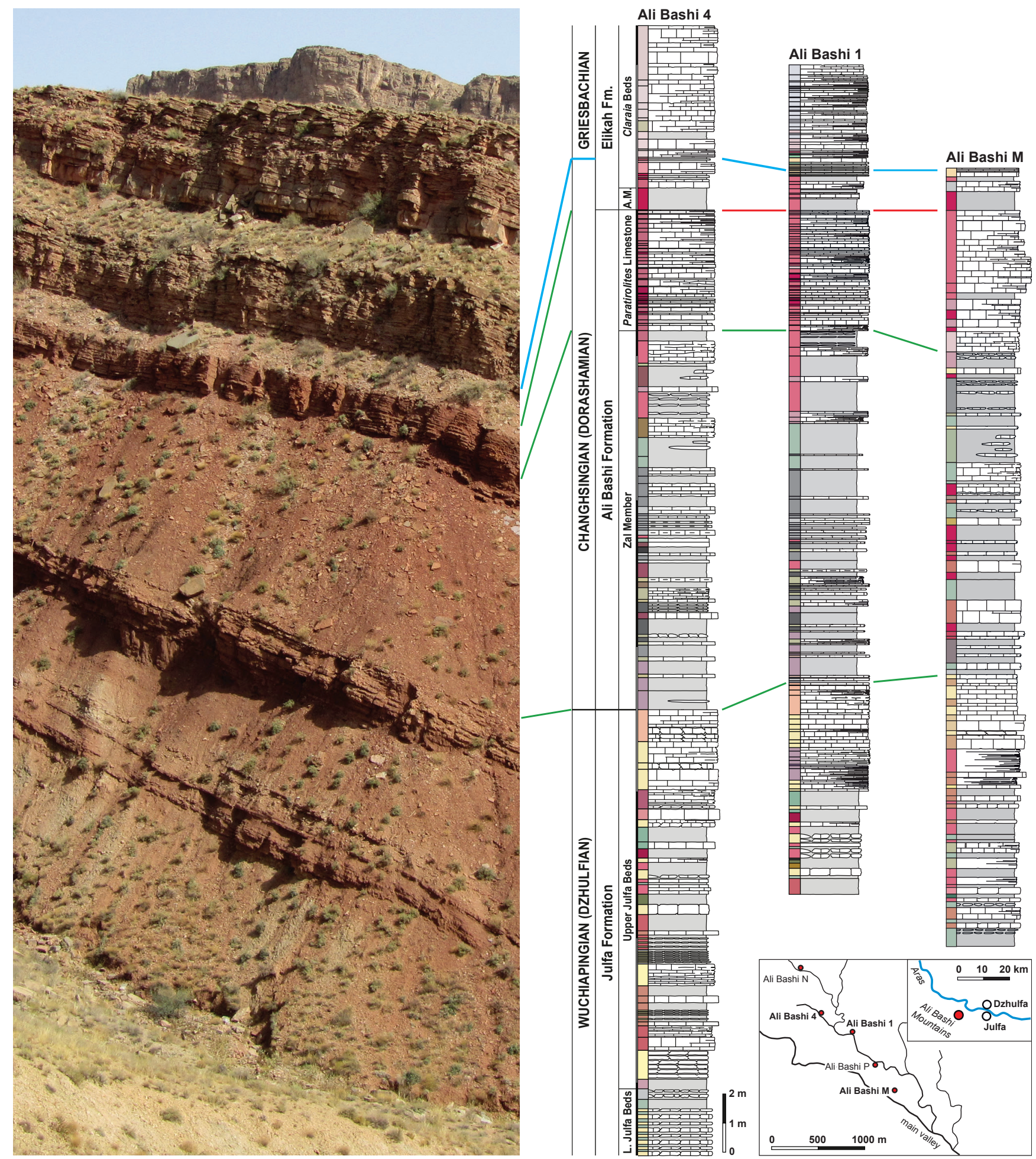

Figure 3. Ali Bashi 4 section and columnar sections of the entire Changhsingian in Ali Bashi 4, Ali Bashi 1 and Ali Bashi M sections with their conodont zonation. 
new studies, and $16 \mathrm{~m}$ in the Zal section. All the mentioned sections show a very similar rock succession, which is dominated by dark-grey shales at the base turning violet-reddish towards the top. Marly and nodular limestone beds are intercalated and occur usually in packages; they are grey at the base of the member and red to pink at the top. The member is only occasionally rich in macrofossils, of which ammonoids, nautiloids and small brachiopods are the most common.

In the sections in Armenia and the northern part of Nakhichevan, the member is extremely reduced in thickness (Arakelyan et al., 1965). The shales are nearly absent there with the result that the entire member has a thickness of only 2-5 $\mathrm{m}$ in the Armenian sections of Vedi, Zangakatun (i.e. Khanakhchi or Sovetashen in the literature), and Ogbin (Rostovtsev and Azaryan, 1973).

(b) Paratirolites Limestone Member - the Paratirolites Limestone has a similar lithological appearance in all studied sections; usually it shows thicknesses ranging between about 4 and $5 \mathrm{~m}$ (Aras Valley: $4.60 \mathrm{~m}$, Ali Bashi N: $4.50 \mathrm{~m}$, Ali Bashi 4: $4.15 \mathrm{~m}$, Ali Bashi 1: $4.15 \mathrm{~m}$, Zal: $5.10 \mathrm{~m}$ ). The unit is composed of 5 to $30 \mathrm{~cm}$-thick, red nodular marly limestone beds with a $\mathrm{CaCO}_{3}$ content ranging between 80 and 96 weight \% (Fig. 4). It is typically developed in the Julfa area (Stepanov et al., 1969; Teichert et al., 1973), but similar sedimentary rocks occur in central Iran (e.g. Taraz, 1971; Taraz et al., 1981; Leda et al., 2014).

The carbonate microfacies of the Paratirolites Limestone has been intensely described by Leda et al. (2014); there it was shown that the unit is largely uniform but can be separated into two subunits because of microfacies characters:

(1) The base of the Paratirolites Limestone shows some rather compact limestone beds of $10-30 \mathrm{~cm}$ thickness; they are clearly separated by red shale and marl horizons $\left(\mathrm{CaCO}_{3}\right.$ down to 54 weight \%). Distinct limestone beds can easily be correlated between neighbouring sections. The shale intercalations, which become much less prominent higher in the section, occasionally contain limestone nodules. In the middle of the Paratirolites Limestone (i.e. about 1.90 to $2.00 \mathrm{~m}$ below the top of the unit), a conspicuous limestone bed occurs in the Aras and Ali Bashi sections. This bed differs, in its much lighter colour and denser matrix, from the other beds of the Paratirolites Limestone. It works as a lithological index horizon in all studied sections around Julfa (Fig. 4). The clear separation between limestone beds and shale intercalations at the base of the Paratirolites Limestone diminishes towards the top of the member, but here an alternation of more compact limestone beds and horizons richer in clay can be recorded.

(2) The upper part $(0.30 \mathrm{~m}$ thick in the Ali Bashi 1 section) of the Paratirolites Limestone shows evidence of stratigraphical condensation; it contains isolated nodules, which occasionally possess black ferruginous and manganese coatings and are preserved as hard-ground clasts (Leda et al., 2013).
A lithostratigraphical correlation of the sections of the Paratirolites Limestone in NW Iran can be performed by the use of limestone-clay alternations.

2. Elikah Formation - the majority of this formation belongs to the Triassic, and only the lowermost portion, described as "boundary clay" by Leda et al. (2014), is of Late Permian age. This will be described here as the Aras Member.

Aras Member (with the type locality in the Aras Valley section) - these beds represent the transition from the Permian into the Triassic; the shale-dominated member marks a drastic reduction of $\mathrm{CaCO}_{3}$, down to 15-30 weight $\%$. A detailed description of the occurrence in the Dorasham $2 \mathrm{sec}-$ tion was provided by Zakharov (1992), and conodont faunas from the unit in the Ali Bashi Mountains were described by $\operatorname{Kozur}(2004,2005,2007)$. The carbonate microfacies and the fossil inventory were outlined by Leda et al. (2014).

The member has a variable thickness in the investigated sections and range from $0.50 \mathrm{~m}$ in the $\mathrm{Zal}$ section to $3.00 \mathrm{~m}$ in the Aras Valley section. It is largely composed of dark red to brownish shales with occasionally occurring greenish-grey intervals and thin marly limestone intercalations towards the top of the unit. A 10-centimetre-thick grey nodular limestone bed occurs as a lenticular intercalation in the Zal section.

The Aras Member is poor in macrofossils. Leda et al. (2014) showed that concentrations of sponge spicules and ostracods occur occasionally in thin carbonate-enriched horizons in the middle and upper part of the member; further macrofossils are rare gastropods and bivalves. Zakharov (1992) investigated the unit, which is well-exposed in the Dorasham section, in greater detail.

\section{Conodont stratigraphy (Ghaderi, Ashouri)}

The conodont biostratigraphy of the Changhsingian deposits of north-western Iran has been published in several pioneering papers (e.g. Sweet in Teichert et al., 1973; Kozur, 1975, 1978). A more precise resolution followed thereafter by Kozur $(2004,2005)$ and Shen and Mei (2010). Kozur (2005) subdivided the Changhsingian successions of north-west and central Iran into 10 conodont biozones, in ascending order: the Clarkina hambastensis, C. subcarinata, C. bachmanni, C. nodosa, C. changxingensis-C. deflecta, C. zhangi, C. iranica, C. hauschkei, C. meishanensis-Hindeodus praeparvus and Merrillina ultima-Stepanovites ?mostlerizones (Fig. 5).

According to Kozur (2005), the $C$. hambastensis and $C$. subcarinata biozones were recognized in the shaly unit (here described as Zal Member) of the Ali Bashi Formation. The Paratirolites Limestone includes the next six conodont biozones, and the upper two biozones ( $C$. meishanensis- $H$. praeparvus and Merrillina ultima-Stepanovites ?mostleri) are situated within the boundary clay (here described as the Aras Member).

Later, Shen and Mei (2010) re-evaluated all collected and reported conodont materials by Teichert et al. (1973), ICRG 


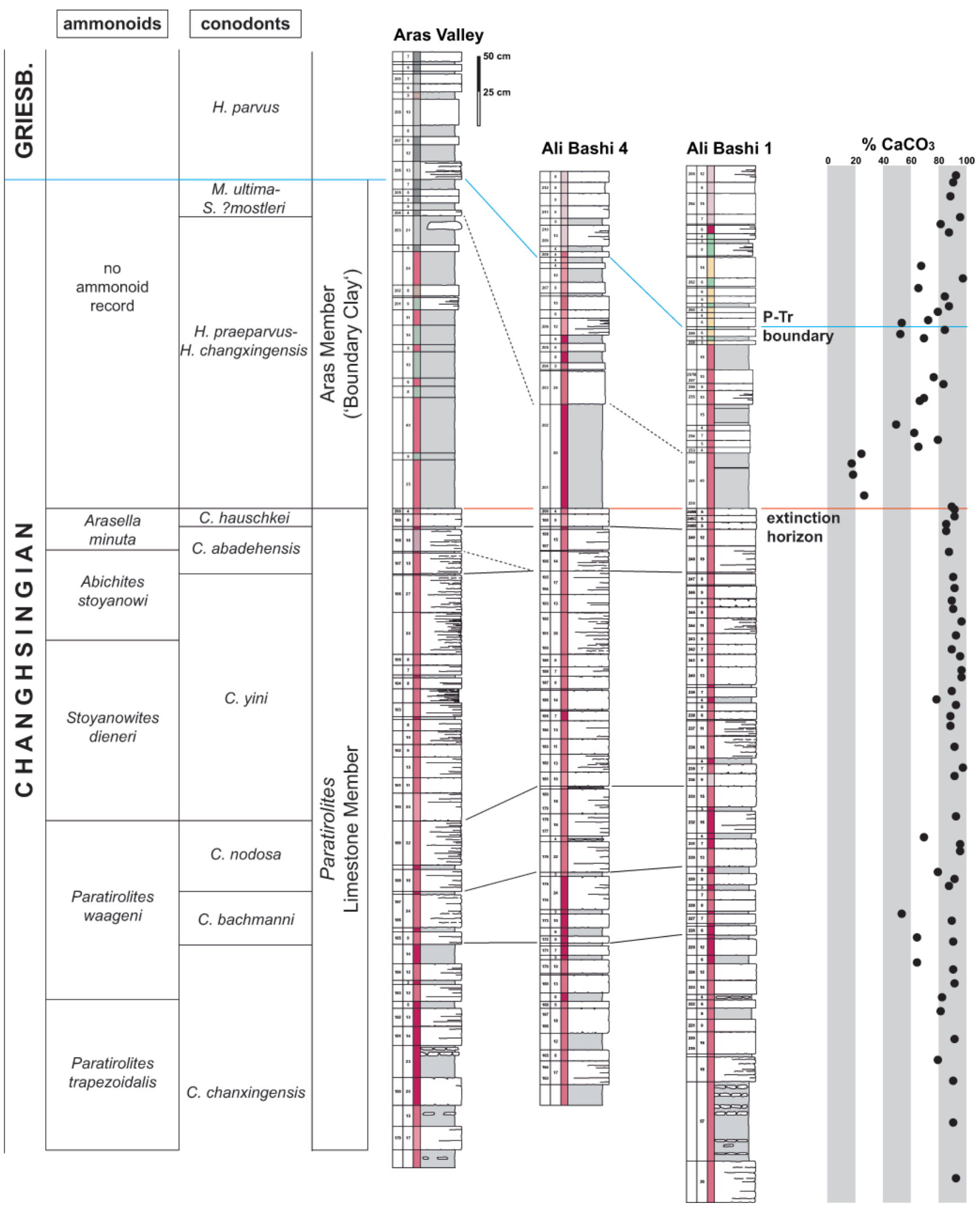

Figure 4. Columnar sections of the Paratirolites Limestone in the Aras Valley, Ali Bashi 4 and Ali Bashi 1 sections with their conodont and ammonoid zonation as well as the weight $\%$ of $\mathrm{CaCO}_{3}$ (determined by the weight loss-acid digestion method) of the Ali Bashi 1 section. 


\begin{tabular}{|c|c|c|c|c|c|c|}
\hline \multirow[b]{3}{*}{$\underline{\mathbf{n}}$} & \multirow[b]{3}{*}{$\frac{\alpha}{\sigma}$} & \multicolumn{3}{|c|}{ conodonts } & \multicolumn{2}{|c|}{ ammonoids } \\
\hline & & new data & Kozur $(2005,2007)$ & Shen \& Mei (2010) & new data & Shevyrev (1965) \\
\hline & & H. parvus & H. parvus & H. parvus & & \\
\hline \multirow{6}{*}{$\begin{array}{l}z \\
<\end{array}$} & \multirow{5}{*}{$\frac{z}{4}$} & $\begin{array}{l}\text { M. ultima- } \\
\text { S. ?mostleri }\end{array}$ & $\begin{array}{l}\text { M. ultima- } \\
\text { S. ?mostleri }\end{array}$ & & (no ammonoid data) & (no ammonoid data) \\
\hline & & $\begin{array}{r}\text { H. praeparvus- } \\
\text { H. changxingensis }\end{array}$ & $\begin{array}{c}\text { C. meishanensis- } \\
\text { H. praeparvus }\end{array}$ & C. hauschkei & & \\
\hline & & C. hauschkei & C. hauschkei & & $\begin{array}{l}\text { Arasella } \\
\text { minuta }\end{array}$ & \multirow{7}{*}{ Paratirolites Beds } \\
\hline & & C. abadehensis & C. iranica & C. abadehensis & Abichites & \\
\hline & & & C. zhangi & & stoyanowi & \\
\hline & $\boldsymbol{\infty}$ & C. yini & C. chanx.-C. defl. & C. yini & Stoyanowites dieneri & \\
\hline \multirow{8}{*}{$\begin{array}{l}\bar{\Sigma} \\
\boldsymbol{\alpha} \\
\mathbf{n}\end{array}$} & $\frac{I}{0}$ & C. nodosa & C. nodosa & C. nodosa & $\begin{array}{l}\text { Paratirolites } \\
\text { waageni }\end{array}$ & \\
\hline & $z$ & C. bachmanni & \multirow{3}{*}{ C. bachmanni } & C. bachmanni & Paratirolites & \\
\hline & $I$ & C chanyingencic & & C shanyingancis & trapezoidalis & \\
\hline & \multirow{4}{*}{$\frac{1}{U}$} & c. chanxingensis & & c. chanxingensis & Shevyrevites shevyrevi & Bernhardites Beds \\
\hline & & C subcarinata & C subcarinata & C subcarinata & Dzhulfites nodosus & Dzhulfites Beds \\
\hline & & U. Sunc al illata & C. Sunclarmiata & U. Suncairitiata & \multirow{2}{*}{$\begin{array}{l}\text { Iranites transcaucasius - } \\
\text { Phisonites triangulus }\end{array}$} & Tompophiceras Beds \\
\hline & & $\begin{array}{l}\text { C. orientalis- } \\
\text { C. subcarinata int. }\end{array}$ & C. hambastensis & C. wangi & & Phisonites Beds \\
\hline & 3 & C. orientalis & C. orientalis & C. orientalis & $\begin{array}{l}\text { Vedioceras } \\
\text { umbonavarum }\end{array}$ & Vedioceras Beds \\
\hline
\end{tabular}

Figure 5. The correlation of the conodont schemes by Kozur (2005, 2007), Shen and Mei (2010) and own results with the ammonoid stratigraphy by Shevyrev (1965) and own results.

(Iranian-Chinese Research Group) (1995), Yazdi and Shirani (2002) and Kozur $(2004,2005,2007)$ based on the samplepopulation approach. They proposed eight biozones for the Changhsingian deposits of Iran, thus differing from Kozur's zonation. Their conodont biozones in ascending order are as follows: the Clarkina wangi, C. subcarinata, C. changxingensis, C. bachmanni, C. nodosa, C. yini, C. abadehensis and C. hauschkei zones (Fig. 5).

In their subdivision, the $C$. wangi and $C$. subcarinata zones are located in the Zal Member and the other biozones are distinguishable in the Paratirolites Limestone and the boundary clay (Aras Member).

We studied four sections by bed-by-bed sampling: the Aras Valley section as well as the Ali Bashi section 4, 1 and M. Our investigations, which apply the sample-population taxonomic approach (Mei et al., 2004), led to the separation of 10 conodont biozones for the Changhsingian sections of the Julfa area (Fig. 5, Table 1). Characteristic conodont specimens are illustrated in Fig. 6.

The zones are in ascending order:

1. Clarkina orientalis-Clarkina subcarinata interval zone (equivalent to the $C$. wangi Zone) - the new $C$. orientalis$C$. subcarinata interval zone is defined in the sections near
Julfa by the last occurrence of $C$. orientalis until the first occurrence of $C$. subcarinata.

The equivalent strata with this interval in the Meishan section (Zhejiang, South China) are regarded as C. wangi Zone by Mei et al. (2004) based on the first appearance of $C$. wangi, the base marker of Changhsingian stage. Jin et al. (2001) proposed the Global Boundary Stratotype Section and Point (GSSP) for the Wuchiapingian-Changhsingian stage boundary by the first appearance of $C$. wangi within the lineage from $C$. longicuspidata to $C$. wangi at Meishan section $\mathrm{D}$ above the flooding surface of the second parasequence in the Changxing Limestone.

This stage boundary was questioned by Kozur (2005), because he regarded $C$. hambastensis Kozur 2004 as the best index species for a definition of the WuchiapingianChanghsingian boundary. He therefore proposed the new $C$. hambastensis Zone based on the first appearance of $C$. hambastensis for the base of "Dorashamian" in the Hambast Mountains (Abadeh area, central Iran) instead of C. wangi, which was absent in his materials from Iran. However he reported the species $C$. hambastensis only from the Shahreza section and from sections V and VI of the Hambast Mountains, but not from the Julfa area. 


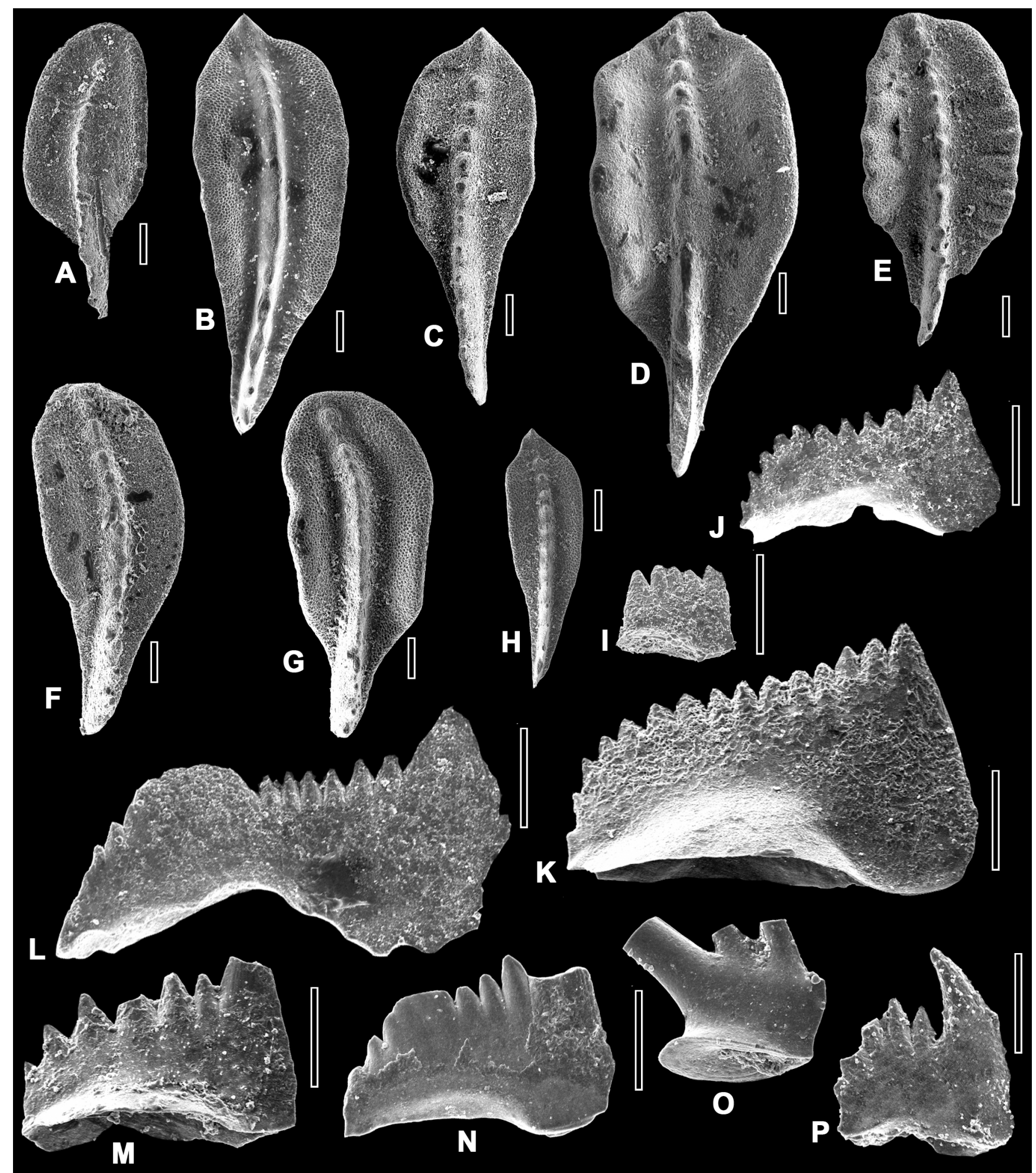

Figure 6. 
Figure 6. Characteristic Changhsingian conodonts from the Julfa region (scale bars equal to $100 \mu \mathrm{m}$ ); all specimens stored in the collection of the Ferdowsi University, Mashhad. (A) Clarkina orientalis (Barskov and Koroleva, 1970); FUM\#1J192.1; upper Julfa beds (Vedioceras beds), Ali Bashi 1 section. (B) Clarkina subcarinata Sweet, 1973; FUM\#4J142.8; Zal Member (Ali Bashi Formation), Ali Bashi 4 section. (C) Clarkina changxingensis Wang and Wang, 1981; FUM\#4J153.1; Zal Member (Ali Bashi Formation), Ali Bashi 4 section. (D) Clarkina bachmanni Kozur, 2004; FUM\#AJ185.23; Paratirolites Limestone (Ali Bashi Formation), Aras Valley section. (E) Clarkina nodosa Kozur, 2004; FUM\#G249.16; Paratirolites Limestone (Ali Bashi Formation), Ali Bashi M section. (F) Clarkina yini Mei, 1998; FUM\#AJ192.4; Paratirolites Limestone (Ali Bashi Formation), Aras Valley section. (G) Clarkina abadehensis Kozur, 2004; FUM\#1J248.9; Paratirolites Limestone (Ali Bashi Formation), Ali Bashi 1 section. (H) Clarkina hauschkei Kozur, 2004, FUM\#1J249D.9; Paratirolites Limestone (Ali Bashi Formation), Ali Bashi 1 section. (I) Hindeodus eurypyge Nicoll, Metcalfe and Wang, 2002, FUM\#1J255.7 (cusp broken); Zal Member (Ali Bashi Formation), Ali Bashi 1 section. (J) Hindeodus typicalis Sweet, 1970, FUM\#G233.5; Paratirolites Limestone (Ali Bashi Formation), Ali Bashi M section. (K) Hindeodus typicalis Sweet, 1970, FUM\#4J200.56; Paratirolites Limestone (Ali Bashi Formation), Ali Bashi 4 section. (L) Hindeodus julfensis Sweet, 1973, FUM\#1J198.4; Zal Member (Ali Bashi Formation), Ali Bashi 4 section. (M) Hindeodus praeparvus Kozur, 1996, FUM\#G274.6 (cusp broken); Aras Member (Elikah Formation), Ali Bashi M section. (N) Hindeodus changxingensis Wang, 1995, FUM\#4J201.6 (cusp broken); Aras Member (Elikah Formation), Ali Bashi 4 section. (O) Merrillina ultima Kozur, 2004, FUM\#AJ204.13; Aras Member (Elikah Formation), Aras Valley section. (P) Hindeodus parvus Kozur and Pjatakova, 1976, FUM\#4J213.1; Elikah Formation; Ali Bashi 4 section.

Table 1. Thickness (in metres) of the conodont zones in sections in the area of Julfa.

\begin{tabular}{|c|c|c|c|c|}
\hline Zone & Ali Bashi section 1 & Ali Bashi section 4 & Ali Bashi section M & Aras Valley \\
\hline M. ultima-S. ?mostleri Zone & 0.92 & 1.06 & 0.53 & 0.25 \\
\hline H. praeparvus-H. changxingensis Zone & 0.40 & 0.80 & 0.65 & 2.30 \\
\hline C. hauschkei Zone & 0.15 & 0.13 & 0.15 & 0.13 \\
\hline C. abadehensis Zone & 0.31 & 0.30 & 0.35 & 0.18 \\
\hline C. yini Zone & 1.51 & 1.55 & 1.50 & 1.95 \\
\hline C. nodosa Zone & 0.58 & 0.62 & 0.45 & 1.25 \\
\hline C. bachmanni Zone & 0.48 & 0.51 & 0.35 & 0.38 \\
\hline C. changxingensis Zone & 6.70 & 6.72 & 6.95 & 4.30 \\
\hline C. subcarinata Zone & 5.40 & 5.20 & 5.20 & 4.58 \\
\hline C. orientalis - C. subcarinata interval zone & 0.85 & 1.10 & 0.90 & 1.65 \\
\hline
\end{tabular}

Kozur (2005) suggested that a correlation of the Wuchiapingian-Changhsingian stage boundary of sections in Iran and South China is possible because $C$. hambastensis is also present in Changhsingian beds of the South Chinese intraplatform basins, where it was assigned to $C$. wangi by Jin et al. (2003). However, in the Iranian sections $C$. hambastensis appears somewhat earlier than true $C$. wangi, which is the marker for the base of the Changhsingian in China. Therefore, he proposed that this biozone is more complete in Iran, and the largest part of the $C$. hambastensis Zone is missing because of a gap in the Meishan section.

Henderson et al. (2008) confirmed the $C$. wangi Zone in the $\mathrm{Zal}$ section, but he did not provide any illustrations of the conodonts. The $C$. wangi Zone was also confirmed by Shen and Mei (2010) from sections in Iran, but again without any illustrations of the materials. In their paper (and in Nafi et al., 2006; Chen et al., 2008) C. hambastensis was regarded as a probable synonym of $C$. wangi. Shen and Mei (2010) indicated that $C$. hambastensis is less common in the population of $C$. wangi in South China. They wrote "if it can be established that $C$. hambastensis is more common in the sample-population of $C$. wangi in Iran than South China, $C$. hambastensis can be regarded as a subspecies or a geographical cline of $C$. wangi."

Our new investigations indicate there are no $C$. hambastensis or $C$. wangi specimens in the four investigated sections of the Julfa area. In the Ali Bashi sections 1 and 4 and Aras Valley, the $C$. orientalis Zone (equal to Vedioceras Zone according to the classical ammonoid stratigraphy) is overlain by $1-2 \mathrm{~m}$ of dark shale (base of the Ali Bashi Formation) with some intercalations of marly limestone. These are barren of clarkinids, but with many specimens of $H$. typicalis, $H$. julfensis, Merrillina sp. and some chondrichthyan teeth in all sections. The first carbonate rock unit above the mentioned shaly interval contains typical $C$. subcarinata specimens and a few other conodonts, but it is not possible to ascribe them to $C$. wangi.

We assume that there is no $C$. wangi or its probable synonym $C$. hambastensis in the sections of the Julfa area. At the same time, there are no traces of a sedimentary gap between the $C$. orientalis and $C$. subcarinata biozones. Hence, it would be possible to explain the lack of $C$. wangi with replacement by a hindeodid fauna due to changes in sedimentary facies and environmental conditions. 
All sections in the Julfa area show that there are six short intervals within the Changhsingian, in which the clarkinid conodont fauna is replaced or strongly influenced by a hindeodid fauna or Merrillina sp. The first of these replacements is situated above the uppermost part of the Wuchiapingian succession, where the $C$. orientalis Zone is replaced by $H$. typicalis, H. julfensis and Merrillina sp. in the $C$. orientalis$C$. subcarinata interval zone (equal to $C$. wangi Zone).

Comparison of the replacement horizons with the $\delta^{13} \mathrm{C}$ curve of the Ali Bashi section 1 (Schobben et al., 2013) demonstrates minor to major accordance between the rise of hindeodid / clarkinid ratio $(H / C$ ratio) and a negative excursion of the $\delta^{13} \mathrm{C}$ curve. Faunal changes in these intervals were regarded as a replacement of a warm-water fauna by cool water forms (Kozur, 2005, 2007; Korte and Kozur, 2011). However, a correlation of $H / C$ ratio and the $\delta^{18} \mathrm{O}$ curve of the Ali Bashi section 1 (Schobben et al., 2013) cannot support this assumption.

According to Lai et al. (2001), the replacement of the Clarkina fauna by the Hindeodus fauna in P-Tr boundary deposits of the Meishan section is caused by the oxygen depletion in the basin, because clarkinids could not inhabit dysoxic-anoxic bottom waters. Lithology will support this idea, although at the moment we do not have enough measurements to state if anoxia or a change in the temperature from warm water to cool water in the $C$. orientalis-C. subcarinata interval zone caused the faunal replacement.

Lithological and palaeoenvironmental differences may explain the lack of $C$. hambastensis in the Julfa area and its appearance in the Shahreza and Hambast Mountain sections, which was reported by Kozur (2005). The lower shaly part of the Ali Bashi Formation in the Julfa area has carbonate equivalent intervals in the central Iran sections. Hence, there are no conspicuous changes in lithology and palaeoenvironmental conditions between the Vedioceras Zone and the $C$. hambastensis Zone in the Wuchiapingian-Changhsingian boundary interval in central Iran, and thus $C$. hambastensis could be present.

2. Clarkina subcarinata Zone - the base of this zone is defined by the first occurrence of the nominal species $C$. subcarinata, which was first recognized by Sweet in Teichert et al. (1973). In north-western Iran and Meishan, this zone is succeeded by the $C$. changxingensis Zone. However, Kozur (2005) placed the C. bachmanni Zone directly on top of the $C$. subcarinata Zone in Iran. $C$. subcarinata gradually evolves into $C$. changxingensis by reduction of posterior denticles and the gradual development of a gap between the cusp and posterior denticles (Mei et al., 1998a, and Shen and Mei, 2010).

The second and third replacement instances of clarkinids by hindeodids occur in the lower and upper parts of the $C$. subcarinata Zone. These replacements are supported by the dominance of $H$. typicalis and $H$. julfensis over $C$. subcarinata communities.
3. Clarkina changxingensis Zone - the first occurrence of $C$. changxingensis marks the base of this zone. Wang and Wang in Zhao et al. (1981) first defined the $C$. changxingensis Zone in the Meishan section. Elements of $C$. changxingensis are differentiated from those of its probable predecessor, $C$. subcarinata, by the relatively more strongly reduced posterior denticles of many individuals and, thus, by a more distinct depression between the cusp and posterior denticles in the carina profile (Shen and Mei, 2010).

The numbers of $H$. typicalis and $H$. julfensis increased in the fourth $H / C$ replacement in the upper part of the $C$. changxingensis Zone. The $C$. bachmanni Zone begins directly above this major replacement.

4. Clarkina bachmanni Zone - in the Meishan section, the $C$. changxingensis Zone is succeeded by the $C$. yini Zone (Mei et al., 1998b). Kozur (2005) established the $C$. bachmanni Zone based on the full range of the nominate species $C$. bachmanni for the sections in central and north-western Iran. Because of the absence of $C$. bachmanni in the equivalent interval of the Meishan section, Kozur (2005) interpreted a gap in this section. Later, C. bachmanni, which has a short and broad platform with posterior pointed protrusion of the carina, was considered as a transitional morphotype between the round and narrow morphotypes of $C$. yini by Chen et al. (2008) and as a geographical variant of $C$. yini by Shen and Mei (2010). Individuals of $C$. bachmanni are very common in the sections of the Julfa area, especially in the Ali Bashi Mountains.

5. Clarkina nodosa Zone - the base of the $C$. nodosa Zone, which was first defined by Kozur (2005) from Iranian sections, is recognizable by the first occurrence of the nominate species. This full range zone above the $C$. bachmanni Zone yielded numerous specimens with wrinkled upper platform surfaces and with nodes and broad ridges. These wrinkled specimens were first illustrated by Sweet in Teichert et al. (1973) and were later named $C$. nodosa by Kozur (2004). He interpreted the absence of the $C$. nodosa as well as the $C$. bachmanni zones in the Meishan section as andication of a gap. Later, Shen and Mei (2010) referred to this biozone as sample 22-14 (i.e. upper part of Bed 22) in the Meishan section, which contains individuals whose platforms are only slightly wrinkled compared to those from Iran (unpublished data).

6. Clarkina yini Zone - this biozone is defined by the first occurrence of $C$. yini, which in the Meishan section follows the $C$. changxingensis Zone and is itself overlain by the C. meishanensis Zone (Mei et al., 1998b). The stratigraphical scheme is somewhat different in the sections in northwestern Iran, where the $C$. bachmanni and $C$. nodosa zones are very well preserved between the $C$. changxingensis and C. yini zones. Kozur $(2005,2007)$ regarded representatives of the $C$. yini Zone as belonging to either his $C$. changxingensis-C. deflecta Zone below or the $C$. zhangi Zone above, 
which directly follow the $C$. nodosa Zone. Although the boundary between his $C$. changxingensis- $C$. deflecta and $C$. zhangi zones is not well defined, the mentioned species range into the higher biozones.

Mei et al. (1998b) assigned C. zhangi to narrow morphotypes of $C$. yini based on the sample-population approach. $C$. changxingensis was based originally on the round morphotypes, and $C$. deflecta was based on squared morphotypes. Using this diagnosis and the sample-population approach, Shen and Mei (2010) explained why C. changxingensis and $C$. deflecta of Kozur (2005) range into the $C$. yini Zone. We confirm here the view of Shen and Mei and suggest that the $C$. changxingensis-C. deflecta and C. zhangi zones of Kozur (2004, 2005), which are the lower and upper equivalents of the $C$. yini Zone, should be combined to a unique biozone.

The fifth replacement of clarkinid by hindeodid fauna occurs at about $0.50 \mathrm{~m}$ above the base of $C$. yini Zone in Ali Bashi Locality 1 and 4 sections and continues upwards till $0.90 \mathrm{~m}$ from the zonal base. This interval is characterized by a major invasion of small $H$.typicalis and intense reduction of clarkinids. The $H / C$ ratio is associated with some fluctuations in $C$. yini Zone and allow us to consider two major amplifications in $H / C$ ratio: first enrichment at about $0.50 \mathrm{~m}$ above the base of $C$. yini Zone and the second one at $1.15 \mathrm{~m}$ distance from the base in section 1 and $1.18 \mathrm{~m}$ distance from the base in section 4. Both horizons are equivalent with two unusual negative excursions of $\delta^{13} \mathrm{C}$ in the Paratirolites Limestone.

7. Clarkina abadehensis Zone - the C. yini Zone is followed by the $C$. meishanensis Zone in the South Chinese sections. C. meishanensis has reduced posterior denticles and a wide gap between the usually reclined cusp and the first denticle in many individuals of the sample population in South China (Mei et al., 1998b). The morphological evolution of C. yini is different in the Iranian material where the cusp and posterior carina is reduced and sank into the platform through ontogeny. This different pattern has led Kozur (2004) to the definition of the two new species $C$. abadehensis and $C$. iranica. He used $C$. abadehensis for the wedge-like specimens with a deflected posterior carina and $C$. iranica for the slender to moderately wide specimens without deflected posterior end and with a symmetrical or slightly asymmetrical rounded or narrowly rounded posterior margin. The brim is always very wide in both species. Henderson et al. (2008) regarded $C$. iranica as a junior synonym of $C$. abadehensis, and because of the page priority of $C$. abadehensis, they accepted the name of $C$. abadehensis for this species. Later, Shen and Mei (2010) changed the name of the $C$. iranica Zone established by Kozur (2005) into the $C$. abadehensis Zone. $C$. abadehensis-like specimens are present in the lower part of the C. meishanensis Zone in the Xifanli section (Hubei, South China) (Lai and Zhang, 1999) but have not been confirmed subsequently.
8. Clarkina hauschkei Zone - the C. hauschkei Zone ends at the end-Permian mass extinction horizon. Kozur (2005) established the $C$. hauschkei Zone based on the nominate species $C$. hauschkei, which has a relatively flat platform, a narrowly rounded posterior end and a cusp that is separated from the widely spaced posterior denticles by a wider gap. These features are comparable with those of $C$. meishanensis elements, which occur in the upper part of the $C$. meishanensis Zone. Therefore, we suppose that the $C$. hauschkei Zone is equal to the upper part of the $C$. meishanensis Zone of Meishan. Shen and Mei (2010) stated that $C$. hauschkei probably represents a geographical variant of $C$. meishanensis. Both subspecies of C. meishanensis, C. meishanensis zhangi and C. meishanensis meishanensis are also present in the C. hauschkei Zone in our materials from north-western Iran. This co-occurrence may confirm the assumption by Shen and Mei (2010) that $C$. hauschkei is a geographical variant of $C$. meishanensis.

The sixth and final replacement of clarkinids by hindeodids in the Changhsingian begins in the upper $C$. hauschkei Zone and continues to the basal Triassic H.parvus Zone. H. typicalis, $H$. latidentatus, $H$. changxingensis, $H$. praeparvus, H. eurypyge, $H$. inflatus, Merrillina ultima and Stepanovites ?mostleri are the main hindeodid and ramiform elements and dominate the latest Permian clarkinid-based biozones.

9. Hindeodus praeparvus-Hindeodus changxingensis Zone - Kozur (2005) defined the C. meishanensis-H. praeparvus Zone in the boundary clay (lowermost Elikah Formation), with its lower boundary immediately at the mass extinction horizon. C. meishanensis is already present at the base of the $C$. hauschkei Zone, but rarely continues into the $C$. meishanensis-H. praeparvus Zone (Kozur, 2005). Only a few specimens of $C$. meishanensis were found at the top of the extinction horizon in the four sections during the present study. Instead, $H$. praeparvus and $H$. changxingensis, which appear in the lowest samples of the "boundary clay" for the first time, are very abundant. Thus, we name this interval the $H$. praeparvus $-H$. changxingensis Zone. The appearance of $H$. changxingensis as a characteristic marker index fossil immediately above the extinction horizon has been reported previously from South China (Wang and Wang in Zhao et al., 1981; Mei et al., 1998b), Italy (Wang, 1995; Nicoll et al., 2002), Iran (Kozur, 2004, 2005), Pakistan (Perri and Farabegoli, 2003) and Tibet (Shen et al., 2006). In the Abadeh region, $H$. changxingensis occurs in the upper part of the "boundary clay" - i.e. the upper part of $C$. meishanensis- $H$. praeparvus Zone according to the zonation of Kozur (2005). In the Zal section this species appears $30 \mathrm{~cm}$ above the extinction horizon (Kozur, 2005). In the Ali Bashi sections 1, 4 and M, H. changxingensis appears in the lower part of the "boundary clay". We did not find specimens of $H$. changxingensis in the Aras Valley section, but $H$. praeparvus is abundant there. H. praeparvus has the 

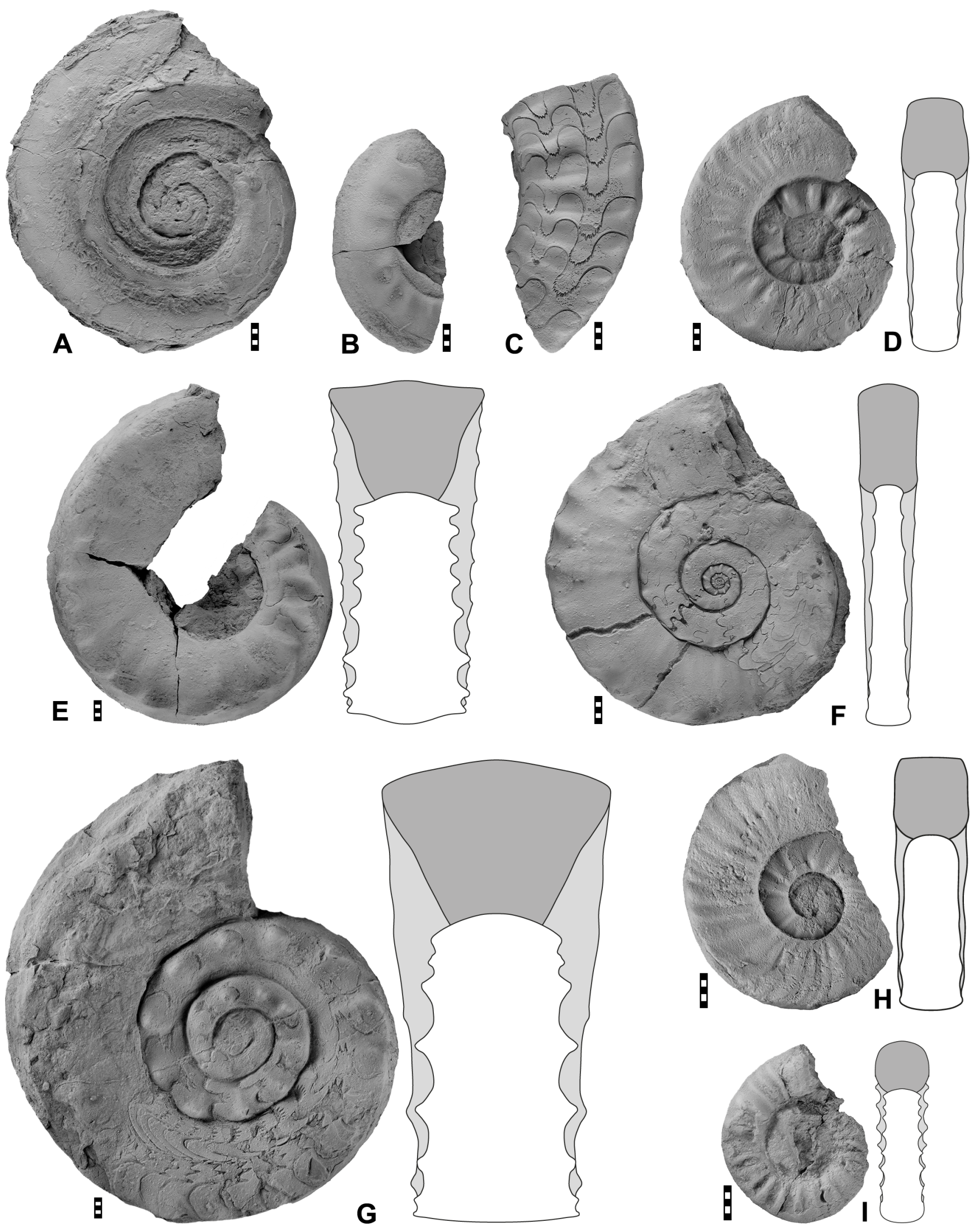

Figure 7. 
Figure 7. Characteristic Changhsingian ammonoids from the Julfa region (scale bars equal to $5 \mathrm{~mm}$ ); all specimens stored in the collection of the Museum für Naturkunde, Berlin. (A) Phisonites triangulus Shevyrev, 1965 from the Aras Valley section, specimen MB.C.22703; × 1.0. (B) Iranites transcaucasius (Shevyrev, 1965) from the Aras Valley section, specimen MB.C.22704; × 1.0. (C) Dzhulfites nodosus Shevyrev, 1965 from the Aras Valley section, specimen MB.C.22705; × 1.0. (D) Shevyrevites nodosus Shevyrev, 1965 from the Aras Valley section, specimen MB.C.22706; × 1.0. (E) Paratirolites trapezoidalis Shevyrev, 1965 from the Ali Bashi 4 section, specimen MB.C.22707; $\times 0.75$. (F) Stoyanowites dieneri (Stoyanow, 1910) from the Aras Valley section, specimen MB.C.22708; $\times 1.0$. (G) Paratirolites vediensis Shevyrev, 1965 from the Ali Bashi N section, specimen MB.C.22709; $\times 0.75$. (H) Abichites stoyanowi (Kiparisova, 1947) from the Ali Bashi N section, specimen MB.C.22710; × 1.25. (I) Arasella minuta (Zakharov, 1983) from the Ali Bashi N section, specimen MB.C.22711; × 1.25.

identical first occurrence in all sections in north-western Iran; however its last occurrence appears to be heterochronous. $H$. changxingensis is limited to the "boundary clay" in the Julfa area sections, but $H$. praeparvus ranges higher into the $H$. parvus Zone.

10. Merrilina ultima-Stepanovites ?mostleri Zone - This biozone contains elements of Merrilina ultima in association with $H$. preparvus and rare $C$. zhejiangensis and was established by Kozur (2005). M. ultima-S. ?mostleri Zone is considered to be correlated with the $C$. zhejiangensis Zone of Mei et al. (1998a, b) in the Meishan section (Kozur, 2005). The presence of this biozone and the $C$. meishanensis $-H$. praeparvus Zone, which was defined by Kozur (2005), was questioned by Shen and Mei (2010). However, these authors did not have any samples with the elements of this biozone in their collections. Our sample populations of this interval yield and confirm the presence of the M. ultima-S. ?mostleri Zone in all sections of the Julfa area. As Kozur (2005) explained, this biozone includes cold water elements dominated by M. ultima, S. ?mostleri, H. praeparvus and very rare C. zhejiangensis, but without its Triassic component, which can be separated by the first appearance of $H$. parvus.

The upper limits of these intervals are characterized by the first appearance of $H$. parvus, which indicates the administrative Permian-Triassic boundary. The first appearance of H. parvus is situated at a distance $1.32 \mathrm{~m}$ in the Ali Bashi Locality $1,1.86 \mathrm{~m}$ in the Ali Bashi Locality 4, $2.75 \mathrm{~m}$ in the Aras Valley section, $1.18 \mathrm{~m}$ in the main valley section.

\section{Ammonoid stratigraphy (Korn)}

The frame for the subdivision of the Changhsingian deposits in the area of Julfa was outlined by Ruzhencev and Shevyrev (1965); they separated five units now regarded as representing the Changhsingian (of which the upper four of these were at that time placed into the Triassic), in ascending order the Phisonites Zone, Tompophiceras Zone, Dzhulfites Zone, Bernhardites Zone and the Paratirolites Zone.

Stepanov et al. (1969) as well as Teichert et al. (1973) followed this scheme, and the latter authors replaced the genus names Tompophiceras and Bernhardites, which originally refer to Triassic ammonoids, by Iranites and Shevyrevites, respectively. Zakharov (1992) added another zone ("Pleuronodoceras occidentale Zone") at the top of the succession, which represents the shaly interval ("boundary clay" of Leda et al., 2014) between the Late Permian and Early Triassic carbonates.

Up to now, a subdivision of the Paratirolites Limestone has not been achieved. Bed-by-bed collections of more than 250 ammonoids from this interval during four field campaigns between 2010 and 2013 offer the opportunity to subdivide this rock unit by means of ammonoid species and genera (Figs. 4, 5). Subdivision of this rock unit is particularly interesting because it has a very different composition (dominated by members of the family Dzhulfitidae) of ammonoids from the occurrences in South China (in which the Dzhulfitidae are either rare or totally missing) (Zhao et al., 1978).

A total of eight biozones (in ascending order) of the Changhsingian interval may be used for regional correlation, of which the lower three represent the lower shaly portion (Zal Member) of the Ali Bashi Formation and the upper five the Paratirolites Limestone (characteristic ammonoid specimens are illustrated in Fig. 7):

1. Iranites transcaucasius-Phisonites triangulus Zone according to our collections, the zones separated by Shevyrev (1965) cannot be separated; Iranites transcaucasius (Shevyrev, 1965) was even collected below Phisonites triangulus Shevyrev, 1965. The unit is $7.00 \mathrm{~m}$ thick in the Dorasham 2 section after Arakelyan et al. (1965) and $6.50 \mathrm{~m}$ thick in the Ali Bashi 4 section after Stepanov et al. (1969).

The lowermost part of the Ali Bashi Formation contains ammonoid faunas in low diversity, and the specimens are usually poorly preserved. Iranites transcaucasius (Shevyrev, 1965) and Phisonites triangulus Shevyrev, 1965 occur, together with other smooth ceratitic ammonoids, at the base of the Ali Bashi Formation in the Aras Valley section. Arakelyan et al. (1965) listed frequent specimens of Xenodiscus and Xenaspis from this interval in the Dorasham 2 section. A newly collected fragment of Vedioceras sp. in the shales at the base of the Ali Bashi Formation in the Ali Bashi 1 section demonstrates the change from Vediocerasdominated faunas of the Wuchiapingian to the xenodisciddominated faunas of the Changhsingian in this interval.

2. Dzhulfites nodosus Zone - it is $7.50 \mathrm{~m}$ thick in the Dorasham 2 section after Arakelyan et al. (1965) and $4.60 \mathrm{~m}$ thick in the Ali Bashi 4 section after Stepanovet al. (1969). Shevyrev (1965) described the two species D. nodosus and D. spinosus, which they exclusively attributed to the 
Dzhulfites beds. In our field work we found that D. spinosus occurs also in the following zone.

3. Shevyrevites shevyrevi Zone - it is $5.50 \mathrm{~m}$ thick in the Dorasham 2 section after Arakelyan et al. (1965) and $6.10 \mathrm{~m}$ thick in the Ali Bashi 4 section after Stepanov et al. (1969). Shevyrevites has obviously only a very limited stratigraphical range and characterizes a thin interval of the Ali Bashi Formation below the Paratirolites Limestone. Dzhulfites occasionally occurs in this zone.

4. Paratirolites trapezoidalis Zone - this zone has a position at the base of the Paratirolites Limestone, where the taxonomic diversity of the ammonoid faunas is rather low. This interval contains paratirolitid ammonoids with unsubdivided or bifid prongs of the external lobe. Paratirolites trapezoidalis Shevyrev, 1965 best characterizes this interval, of which the base is difficult to recognize because of the scarcity of fossils at the base of the Paratirolites Limestone.

5. Paratirolites waageni Zone - this interval is characterized by the main occurrence of the genus Paratirolites, of which also Paratirolites vediensis Shevyrev, 1965 can be used as an index fossil besides the nominate species Paratirolites waageni (Stoyanow, 1910). Even without distinct species attribution, specimens of this zone are usually clearly assigned to this zone because of the strongly serrated external, adventive, and lateral lobes. This interval is, in the Aras Valley and Ali Bashi sections, often very fossiliferous and thus easily recognizable.

6. Stoyanowites dieneri Zone - the entry of paratirolitids with laterally compressed whorl sections, of which "Paratirolites dieneri Stoyanow, 1910" performs as the type species for the new genus Stoyanowites, characterizes the next biozone within the Paratirolites Limestone.

7. Abichites stoyanowi Zone - the upper portion of the Paratirolites Limestone is dominated by paratirolitid ammonoids with quadrate or slightly compressed whorl cross sections. Such forms usually belong to the genus Abichites, which possesses a suture line with unsubdivided or bifid prongs of the external lobe.

8. Arasella minuta Zone - at the top of the Paratirolites Limestone is a thin interval, about $30 \mathrm{~cm}$ thick, which is dominated by very small ammonoids with simple suture lines. Arasella minuta (Zakharov, 1983) is the most common of these and can be used for the definition of this zone.

(9). (Pleuronodoceras occidentale Zone) - Zakharov (1992) attributed the lower $2 \mathrm{~m}$ of the "boundary clay" of the Dorasham II section to the Pleuronodoceras occidentale Zone, based on a finding of the nominate species in the basal $9 \mathrm{~cm}$ of the interval. In our study, we did not find ammonoids in the Aras Member and thus cannot confirm this record.
Systematic descriptions, characterization of new taxa:

Order Ceratitida Hyatt, 1884

Suborder Paraceltitina Shevyrev, 1968

Superfamily Xenodiscaceae Frech, 1902

Family Dzhulfitidae Shevyrev, 1965

\section{Stoyanowites n. gen.}

Derivation of name: after A.A Stoyanow, who gave the first description of paratirolitid ammonoids from the Aras Valley.

Type species: Paratirolites Dieneri Stoyanow, 1910.

Diagnosis: genus of the Dzhulfitidae with laterally compressed whorl cross section. Ornament with small ventrolateral nodes and often also dorsolateral nodes. Suture line with short external lobe, which reaches only $60 \%$ of the depth of the adventive lobe.

Discussion: the specimens of the new genus are easily separable from the genera Dzhulfites, Paratirolites and Abichites by the laterally compressed whorl cross section with a ratio of whorl width/whorl height of less than 0.80 (usually more than 1.00 and reaching more than 2.00 in the other three genera).

\section{Arasella n. gen.}

Derivation of name: after the Aras Valley, the locality of the type material.

Type species: Sinoceltites minutus Zakharov, 1983.

Diagnosis: genus of the Dzhulfitidae with small conch reaching $30 \mathrm{~mm}$ diameter. Conch widely umbilicate with circular whorl cross section. Ornament with sharp ribs. Suture line with short external lobe, which reaches only $50 \%$ of the depth of the adventive lobe. Adventive lobe and lateral lobe rounded and unserrated.

Discussion: Zakharov (1983) described the species as belonging to Sinoceltites, a genus belonging to the family Tapashanitidae and known from occurrences in South China. The species has a particular position in two respects: (1) it is obviously the stratigraphically youngest ammonoid to appear before the end-Permian mass extinction event in the NW Iranian sections, and (2) it has a morphology characterized by reduction of morphological characters such as the suture line and thus is difficult to interpret in terms of phylogeny. Two possible phylogenetic origins may be discussed:

(1) A xenodiscid origin - this would imply a ghost lineage ranging through the higher part of the Changhsingian. Evidence of a xenodiscid origin is lacking. 
(2) A paratirolitid origin - this would imply a simplification of conch and suture morphology. Indeed, obvious phylogenetic relationships occur between the stratigraphically older Paratirolites towards the younger Abichites in the reduction of size, the change from trapezoidal towards quadrate whorl cross sections, the disappearance of strong nodes in the sculpture and the reduction of sutural notching. Arasella has some similarities with the stratigraphically younger species of Abichites and may thus be an advanced but morphologically simplified descendent.

Acknowledgements. We thank the Aras Free Zone office for support during our field work. Financial support was provided by the Deutsche Forschungsgemeinschaft (project KO1829/12-1). We acknowledge the preparation of ammonoid specimens by E. Stenzel (Berlin) and check of the English text by S. A. Walton (Berlin). We kindly acknowledge the reviews by Vachik Hairapetian (Esfahan) and Shen Shu-Zhong (Nanjing).

Edited by: F. Witzmann

Reviewed by: S. Shen and V. Hairapetian

\section{References}

Abich, H.: Geologische Forschungen in den kaukasischen Ländern. Theil I. Eine Bergkalkfauna aus der Araxesenge bei Djoulfa in Armenien, 1878.

Arakelyan, R. A., Grunt, T. A., and Shevyrev, A. A.: Kratkiy stratigraficheskiy ocherk, Trudy Paleontologicheskogo Instituta Akademiya Nauk SSSR, 108, 20-25, 1965.

Baud, A., Magaritz, M., and Holser, W.: Permian-Triassic of the Tethys: Carbon isotope studies, Geol. Rundsch., 78, 649-677, 1989.

Bonnet, P. and Bonnet, N. M. T.: Description géologique de la Transcaucasie Méridionale (chaines de l'Araxe Moyen), Mémoires de la Société Géologique de France, Nouvelle Série, 25, 1-292, 1947.

Chen, J., Henderson, C. M., and Shen, S. Z.: Conodont succession around the Permian-Triassic boundary at the Huangzhishan Section, Zhejiang and its stratigraphic correlation, Acta Paleontogica Sinica, 47, 91-114, 2008.

Frech, F.: Lethaea geognostica oder Beschreibung und Abbildung der für die Gebirgs-Formationen bezeichnendsten Versteinerungen, I. Theil. Lethaea palaeozoica, 2. Band, 1897-1902.

Frech, F. and Arthaber, G. V.: Ueber das Palaozoicum in Hocharmenien und Persien, mit einem Anhang uber die Kreide von Sirab in Persien, Beitraege zur Palaeontologie Oesterreich-Ungarns, 12, 161-308, 1900

Ghaderi, A., Ashouri, A. R., Korn, D., Mahmoudi Gharaie, M. H., and Leda, L.: New insight on stratigraphic correlation of the Permian-Triassic transitional beds in the Transcaucasus and northwest of Iran: Problems and guidelines, Sedimentary Facies, 5, 221-246, 2013.

Henderson, C. M., Mei, S., Shen, S., and Wardlaw, B. R.: Resolution of the reported Upper Permian conodont occurrences from northwestern Iran, Permophiles, 51, 2-9, 2008.
Hyatt, A.: Genera of fossil cephalopods, Proceedings of the Boston Society of Natural History, 253-338, 1883-1884.

ICRG (Iranian-Chinese Research Group): Field work on the Lopingian stratigraphy in Iran, Permophiles, 27, 5-8, 1995.

Jin, Y., Henderson, C. M., Wardlaw, B. R., Glenister, B. F., Mei, S., Shen, S., and Wang, X.: Proposal for the Global Stratotype Section and Point (GSSP) for the Guadalupian-Lopingian boundary, Permophiles, 39, 32-42, 2001.

Kakuwa, Y. and Matsumoto, R.: Cerium negative anomaly just before the Permian and Triassic boundary event - The upward expansion of anoxia in the water column, Palaeogeogr. Palaeocl., 229, 335-344, 2006.

Korte, C. and Kozur, H. W.: Carbon-isotope stratigraphy across the Permian-Triassic boundary: A review, J. Asian Earth Sci., 39, 215-235, 2010.

Korte, C. and Kozur, H. W.: Temperature changes across the Permian-Triassic boundary and observations pertaining to some geological/geochemical features around this level, Geol. Soc. Ind. Mem., 78, 100-139, 2011.

Korte, C., Kozur, H. W., and Partoazar, H.: Negative carbon isotope excursion at the Permian/Triassic boundary section at Zal, NW Iran, Hallesches Jahrbuch für Geowissenschaften, Reihe B, Beiheft, 18, 69-71, 2004.

Kozur, H. W.: Beiträge zur Conodontenfauna des Perm, Geologisch-Paläontologische Mitteilungen Innsbruck, 5, 1-44, 1975.

Kozur, H. W.: Beiträge zur Stratigraphie des Perms. Teil II, Die Conodontenchronologie des Perms, Freiberger Forschungshefte, Reihe C: Geowissenschaften, Mineralogie Geochemie, 334, 85$161,1978$.

Kozur, H. W.: The conodonts Hindeodus, Isarcicella and Sweetohindeodus in the uppermost Permian and lowermost Triassic, Geol. Croat., 49, 81-115, 1996.

Kozur, H. W.: Pelagic uppermost Permian and the Permian-Triassic boundary conodonts of Iran. Part 1: Taxonomy, Hallesches Jahrbuch für Geowissenschaften, Reihe B: Geologie Paläontologie Mineralogie, 18, 39-68, 2004.

Kozur, H. W.: Pelagic uppermost Permian and the Permian-Triassic boundary conodonts of Iran. Part II: Investigated sections and evaluation of the conodont faunas, Hallesches Jahrbuch für Geowissenschaften, Reihe B: Geologie Paläontologie Mineralogie Beiheft, 19, 49-86, 2005.

Kozur, H. W.: Biostratigraphy and event stratigraphy in Iran around the Permian-Triassic Boundary (PTB): Implications for the causes of the PTB biotic crisis, Global Planet. Change, 55, 155176, 2007.

Kozur, H. W. and Pjatakova, M.: Die Conodontenart Anchignathodus parvus n. sp., eine wichtige Leitform der basalen Trias, Koninklijke Nederlandse Akademic van Wetenschappen, Proceedings, Series B, 79, 123-128, 1976.

Kozur, H., Leven, E. Y., Lozovskiy, V. R., and Pyatakova, M. V.: Subdivision of Permian-Triassic Boundary beds in Transcaucasia on the basis of conodonts, Int. Geol. Rev., 22, 361-368, 1980.

Lai, X. and Zhang, K.: A new paleoecological model of conodonts during the Permian-Triassic transitional period, Earth Science (Wuhan), 24, 33-38, 1999.

Lai, X. L., Wignall, P., and Zhang, K. X.: Palaeoecology of the conodonts Hindeodus and Clarkina during the Permian-Triassic transitional period, Palaeogeogr. Palaeocl., 171, 63-72, 2001. 
Lasemi, Y., Bagheri, M., and Mahari, R.: Depositional environments and sequence stratigraphy of the Nesen Formation in Zal and Pir-Esagh area (south of Julfa), Journal of Sciences (Islamic Azad University), 17, 73-80, 2007.

Leda, L., Korn, D., Ghaderi, A., Hairapetian, V., Struck, U., and Reimold, W. U.: Lithostratigraphy and carbonate microfacies across the Permian-Triassic boundary near Julfa (NW Iran) and in the Baghuk Mountains (Central Iran), Facies, 60, 295-325, 2014.

Mei, S., Henderson, C. M., and Cao, C.: Conodont samplepopulation approach to defining the base of the Changhsingian Stage, Lopingian Series, Upper Permian, Geological Society, London, Special Publications, 230, 105-121, 2004.

Mei, S.-L., Jin, Y., and Wardlaw, B. R.: Conodont succession of the Guadalupian-Lopingian boundary strata in Laibin of Guangxi, China and West Texas, USA, Palaeoworld, 9, 53-57, 1998a.

Mei, S.-L., Zhang, K. X., and Wardlaw, B. R.: A refined succession of Changhsingian and Griesbachian neogondolellid conodonts from the Meishan section, candidate of the global stratotype section and point of the Permian-Triassic boundary, Palaeogeogr. Palaeocl., 143, 213-226, 1998b.

Nafi, M., Wenchen, X., and Ning, Z.: Late Permian (Changhsingian) conodont biozonation and the basal boundary, Ganxi section, western Hubei Province, south China, Can. J. Earth Sci., 43, 121-133, 2006.

Nicoll, R. S., Metcalfe, I., and Wang, C. Y.: New species of the conodont Genus Hindeodus and the conodont biostratigraphy of the Permian-Triassic boundary interval, J. Asian Earth Sci., 20, 609-631, 2002.

Partoazar, H.: Permian-Triassic boundary conodonts from JolfaAbadeh Belt along Northwest and Central Iran, Permophiles, 41, 34-40, 2002.

Perri, M. C. and Farabegoli, E.: Conodonts across the Permian Triassic boundary in the southern Alps, Cour. For. Senckenbg., 245, 281-313, 2003.

Richoz, S.: Stratigraphie et variations isotopiques du carbone dans le Permien supérieur et le Trias inférieur de la Néotéthys (Turquie, Oman et Iran), Memoirs de Géologie (Lausanne), 46, 1-251, 2006.

Richoz, S., Krystyn, L., Baud, A., Brandner, R., Horacek, M., and Mohtat-Aghai, P.: Permian-Triassic boundary interval in the Middle East (Iran and N. Oman): Progressive environmental change from detailed carbonate carbon isotope marine curve and sedimentary evolution, J. Asian Earth Sci., 39, 236-253, 2010.

Romano, C., Goudemand, N., Vennemann, T. W., Ware, D., Schneebeli-Hermann, E., Hochuli, P. A., Brühwiler, T., Brinkmann, W., and Bucher, H.: Climatic and biotic upheavals following the end-Permian mass extinction, Nat. Geosci., 6, 5760, 2013.

Rostovtsev, K. O. and Azaryan, N. R.: The Permian-Triassic Boundary in Transcaucasia, Canadian Society of Petroleum Geologists Memoir, 2, 89-99, 1973.

Ruzhencev, V. E. and Shevyrev, A. A.: Ammonoidei, in: Razvitie i smena morskikh organizmov na Rubezhe Paleozoya i Mezozoya, edited by: Ruzhencev, V. E. and Sarytcheva, T. G., Trudy Paleontologicheskogo Instituta Akademiya Nauk SSSR, 108, 47-57, 1965.

Ruzhencev, V. E., Sarytcheva, T. G., and Shevyrev, A. A.: Biostratigraficheskie vyvody, in: Razvitie i smena morskikh organiz- mov na Rubezhe Paleozoya i Mezozoya, edited by: Ruzhencev, V. E. and Sarytcheva, T. G., Trudy Paleontologicheskogo Instituta Akademiya Nauk SSSR, 108, 93-116, 1965.

Schobben, M., Joachimski, M. M., Korn, D., Leda, L., and Korte, C.: Palaeotethys seawater temperature rise and an intensified hydrological cycle following the end-Permian mass extinction, Gondwana Res., doi:10.1016/j.gr.2013.07.019, 2013.

Shen, S.-Z. and Mei, S.-L.: Lopingian (Late Permian) highresolution conodont biostratigraphy in Iran with comparison to South China zonation, Geol. J., 45, 135-161, 2010.

Shen, S. Z., Cao, C.-Q., Henderson, C. M., Wang, X.-D., Shi, G. R., Wang, Y., and Wang, W.: End-Permian mass extinction pattern in the northern peri-Gondwanan region, Palaeoworld, 15, 3-30, 2006.

Shevyrev, A. A.: Nadortyad Ammonoidea, in: Razvitie i smena morskikh organizmov na Rubezhe Paleozoya i Mezozoya, edited by: Ruzhencev, V. E. and Sarytcheva, T. G., Trudy Paleontologicheskogo Instituta Akademiya Nauk SSSR, 108, 166-182, 1965.

Shevyrev, A. A.: Triasovye ammonoidei Yuga SSSR, Trudy Paleontologicheskogo Instituta Akademiya Nauk SSSR, 119, 1-272, 1968.

Stampfli, G. M. and Borel, G. D.: A plate tectonic model for the Paleozoic and Mesozoic constrained by dynamic plate boundaries and restored synthetic oceanic isochrons, Earth Planet. Sc. Lett., 196, 17-33, 2002.

Stepanov, D. L., Golshani, F., and Stöcklin, J.: Upper Permian and Permian-Triassic Boundary in North Iran, Geolological Survey of Iran, Report, 12, 1-72, 1969.

Sun, Y., Joachimski, M. M., Wignall, P. B., Yan, C., Chen, Y., Jiang, H., Wang, L., and Lai, X.: Lethally hot temperatures during the early Triassic greenhouse, Science, 338, 366-370, 2012.

Sweet, W. C.: Uppermost Permian and Lower Triassic conodonts of the Salt Range and Trans-Indus Ranges, West Pakistan, in: Stratigraphic boundary problems: Permian and Triassic of West Pakistan, edited by: Kummel, B. and Teichert, C., University of Kansas, Department of Geology, Special Publications, 4, 207275, 1970.

Sweet, W. C. and Mei, S.-1.: The Permian Lopingian and basal Trassic Sequence in Northwest Iran, Permophiles, 33, 14-18, 1999a.

Sweet, W. C. and Mei, S.-1.: Conodont succession of Permian Lopingian and basal Triassic in northwest Iran, Paper read at Proceedings of the International Conference on Pangea and the Paleozoic-Mesozoic transition, China University of Geosciences Press, Wuhan, 1999b.

Taraz, H.: Uppermost Permian and Permian-Triassic Transition beds in Central Iran, Bulletin of the American Association of Petroleum Geologists, 55, 1280-1294, 1971.

Taraz, H., Golshani, F., Nakazawa, K., Sgimuzu, D., Bando, Y., Ishi, K.-i., Murata, M., Okimura, Y., Sakagami, S., Nakamura, K., and Tokuoka, T.: The Permian and the Lower Triassic Systems in Abadeh Region, Central Iran, Memoirs of the Faculty of Science, Kyoto University, Series of Geology and Mineralogy, 47, 61133, 1981.

Teichert, C., Kummel, B., and Sweet, W. C.: Permian-Triassic strata, Kuh-e-Ali Bashi, Northwestern Iran, Bulletin of the $\mathrm{Mu}-$ seum of Comparative Zoology, Harvard University, 145, 359472, 1973. 
Voinova, E. V., Kiparisova, L. D., and Robinson, V. H.: Klass Cephalopoda. Golovonogie, in: Atlas rukovodyashtchikh form iskopaemykh faun SSSR. VIII. Triasovaya sistema, MoskvaLeningrad, 1947.

Wang, C.-y.: Conodonts of Permian-Triassic boundary beds and biostratigraphic boundary, Acta Palaeontologica Sinica, 34, 129 $151,1995$.

Yazdi, M. and Shirani, M.: First research on marine and nonmarine sedimentary sequences and micropaleontologic significance across Permian/Triassic boundary in Iran, (Isfahan and Abadeh), J. China Univ. Geosci., 13, 172-176, 2002.

Zakharov, Y. D.: Ammonoidea, in: Kotlyar, G. V., Zakharov, Yu. D., Koczyrkevich, B. V., Kropatcheva, G. S., Rostovtsev, K. O., Chedia, I. O., Vuks, G. P., and Guseva, E. A.: Dzhul'finskii i Dorashamskii yarusy SSSR, edited by: Gramm, M. N. and Rostovtsev, K. O., Pozdnepermiskii etap evoliutsii organicheskogo mira, 150-157, 1983.
Zakharov, Y. D.: The Permo-Triassic boundary in the southern and eastern USSR and its intercontinental correlation, edited by: Sweet, W. C., Zunyi, Y., Dickins, J. M., and Hongfu, Y., Cambridge, Cambridge University Press, 1992.

Zhao, J., Liang, X., and Zheng, Z.: Late Permian cephalopods from South China, Paleontologica Sinica, N.S. B, 12, 1-194, 1978.

Zhao, J.-K., Sheng, J.-Z., Yao, Z.-Q., Liang, X.-L., Chen, C.Z., Rui, L., and Liao, Z.-T.: The Changhsingian and PermianTriassic boundary of South China, Bulletin of the Nanjing Institute of Geology and Palaeontology, Academia Sinica, 2, 1-95, 1981. 